\title{
STONEWARE FROM THE 14TH TO \\ THE 17 TH CENTURIES FOUND IN \\ ARCHAEOLOGICAL EXCAVATIONS IN VILNIUS
}

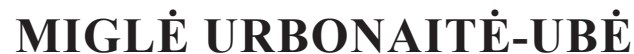

\begin{abstract}
Late Medieval and Early Modern Period stoneware production is often found in archaeological excavations around the world. The identification and analysis of these objects provides information about technical innovations, long-distance trade, and social and economic changes in societies. Stoneware vessels were used for pouring and storing liquids, and thus indicate changing drinking habits. Vessels are dated and classified by their surface treatment, the colour of the stoneware, and their decorative motifs, and are then associated with specific manufacturing centres by using a comparative method. The stoneware in Vilnius was produced at production sites in Siegburg, Cologne, Frechen, Raeren, Westerwald and Waldenburg. The earliest stoneware vessels could be associated with newcomers to the town; while in later periods their distribution indicates higher demand and usage in town dwellers' households.
\end{abstract}

Key words: stoneware, Rhineland, tableware, drinking vessels, Jacobakanne, Vilnius.

DOI: http://dx.doi.org/10.15181/ab.v25i0.1838

\section{Introduction}

Rhenish stoneware production has a history of more than 700 years. It was one of the most successful European craft industries in the Late Middle Ages and the Early Modern Period (Gaimster 2006). Stoneware artefacts are found all over the continent, as well as in North America, Africa, China and Australia (Gaimster 1997). Major productions sites were in present-day Lower Rhineland (Siegburg, Raeren, Cologne, Frechen, Westerwald), and in Saxony (Waldenburg, Annaberg, Freiberg). Numerous excavations during the 20th century allowed us to locate stoneware wasters, which resulted in the successive typochronology of these items (Gaimster 2006). However, the initial research on stoneware conducted by 19th-century antiquarians was mainly focused on stoneware as valuable items on the antique market. Only in the last few decades did archaeologists start to concentrate on the distribution, trading and social aspects of stoneware.

Stoneware is characterised by a fully fused body with extremely low porosity value, with no visible inclusions (Gaimster 1997). Vessels were fired at high temperatures (around 1200 to $1300 \mathrm{C}^{\circ}$ ), which led to the complete fusion of the clay. The success of stoneware vessels in the pottery market is a result of a combination of technology and functionality. A fully fused ceramic body was impervious to water, which made it well suited for storing and transporting liquids (Gaimster 1997). The introduction of applied relief technology during the 16th century allowed stoneware to remain in high demand until the era of industrialisation (Gaimster 1997).

However, until recently, pottery was mainly assessed as an indicator of chronology. Changing approaches in the archaeological field have allowed for the adoption of a new perception of pottery as an indicator of the social and economic situation in a specific time and place. In other words, changes in the form, decoration and technical improvements of vessels are closely related to the political situation and long-distance trade, as well as to important changes in everyday life, such as eating habits or social display. Generally, ceramics in the Medieval and Post-Medieval era perform a vital role as mirrors of change in the material culture (Gaimster 2006). Questions can be answered regarding technical and functional developments, trading mechanisms, changes in eating habits, wealth, and the development of material comforts (Gaimster 2006). Rhenish stoneware producers reacted to these rapidly, by introducing new types of vessels, and innovative decoration and surface treatment techniques.

Studies of imported stoneware are common all over Western Europe, since it is found in most urban sites (Gaimster 2006). According to D. Gaimster (1987, 2006), the identification of these vessels has helped to revise the chronology and provide evidence of longdistance trading mechanisms. Furthermore, studies of pottery in Scandinavia and Eastern Europe have made a significant contribution to our understanding of the social and economic history of this region.

\section{II}

THE MATERIAL OF MEDIEVAL AND NEW AGES: SOCIAL INTERACTIONS BETWEEN COMMUNITIES 
The lack of Late Medieval and Early Modern Period pottery studies in Lithuania has resulted in the necessity to publish artefact studies, especially about imported ware. The identification of these vessels enables us to construct a more reliable chronology of the sites, and most importantly to reconstruct the social and economic changes during a specific period of time. The scarcity of historical sources concerning everyday activities and adopted lifestyles, especially in the early history of Vilnius, makes archaeological material the initial source for social reconstruction. There is a huge collection of pottery excavated in Vilnius stored in museum archives; however, only a few studies have been made of pottery finds. Imported ware was studied briefly, mostly by mentioning it as non-local products. Therefore, analyses of pottery are necessary for understanding the communities of the Late Medieval and Early Modern Period, and their complex social behaviour. Imported pottery is a direct indicator of the changing material culture, and thus an indicator of social and economic behaviour.

In this article, a typology of Rhenish and Saxon stoneware, and an interpretation of their archaeological contexts, is presented, in order to identify these vessels, and to acknowledge their importance among all recovered archaeological material. The analysed stoneware pottery is stored in the National Museum of Lithuania and the National Museum-Palace of the Grand Dukes of Lithuania.

\section{Siegburg stoneware}

The production of fully fused body stoneware started in Siegburg when local potters improved firing techniques. Stoneware production there lasted until the mid-17th century. It is not clear exactly when the introduction of fully fused stoneware appeared, but scientists agree it should have been around the end of the 13 th or the beginning of the 14th century (Gaimster 1997; Roehmer 2007).

The typology of Siegburg pottery production is based on the level of body fusion (proto-stoneware, nearstoneware, and real or fully fused stoneware) (Roehmer 2007). Fully fused stoneware is classified according to the surface treatment: unglazed, ash-glazed and saltglazed (Gaimster 1997). Despite the different surface treatments, the technical aspects of producing Siegburg stoneware, such as the preparation of the clay and the firing conditions, remained almost unchanged until the 17th century (Gaimster 1997; Hook 1997).

All types of Siegburg stoneware are found in the archaeological material from Vilnius; however, the total amount is very small, only 16 vessels dated to be- tween the 14th and the 16th century. Three sherds of unglazed Siegburg stoneware were uncovered during excavations of the northern part of the Lower Castle in the early $1970 \mathrm{~s}$, which can be dated to the 14th century (Tautavičius 1962, Fig. 1.1-2). The surfaces of the fragments were light grey, and partly covered in black residue. According to the associated forms, these sherds belonged to tall and slender Jacobakanne jugs. These jugs were typical vessels of the Siegburg centre at that time, and were produced until the mid15 th century. Jacobakanne jugs can be identified by their characteristic thumbed feet, body cordons, rilling and ring handles (Gaimster 1987, 1997). These vessels were used to serve and drink different kinds of drinks. Tall and slim ones were mostly used for wine, with a wider neck for beer (Gaimster 1997).

An on-going analysis of imported pottery in Vilnius shows that Siegburg pottery was introduced to households in the Lower Castle some time around the 14th century, but it only appeared in the Old Town in the 15 th century. Taking into account the fact that these Jacobakanne jugs had no traces of ash glaze, they can be dated to the 14 th century.

Ash glaze was introduced by Siegburg potters around the early 15 th century, and this surface treatment remained until the mid-16th century, when salt-glazed vessels appeared. Ash-glazed Siegburg stoneware is identified by a rough intense orange or reddish yellow surface, and an off-white section colour. The intense colour of the surface was obtained by adding ash to the surface of the vessels, or it appeared naturally during the firing process from the burning timber (Rice 2005). Due to the natural circulation of ash in firing kilns, the surfaces of vessels were glazed unevenly, and some parts were left unglazed. Besides Jacobakanne jugs, new forms of vessels were produced in Siegburg, such as drinking bowls, also known as Schalen, drinking jugs and beakers. Eight small fragments of ash-glazed vessels were identified in the archaeological material from Vilnius. One Jacobakanne jug with thumbed feet was identified; other fragments can be attributed to drinking jugs or beakers.

The 16th century was marked by significant changes in social and cultural practices. Around the mid-16th century, Siegburg potters introduced new forms and decoration of vessels. This was probably under the influence of the newly established Cologne stoneware production site, where potters started using mould technology in the application of relief ornamentation (Gaimster 1997; Roehmer 2007). During the 16th century, tall cylindrical tankards, also known as Schnelle, with applied relief panels, were the most common products from Siegburg and other stoneware produc- 


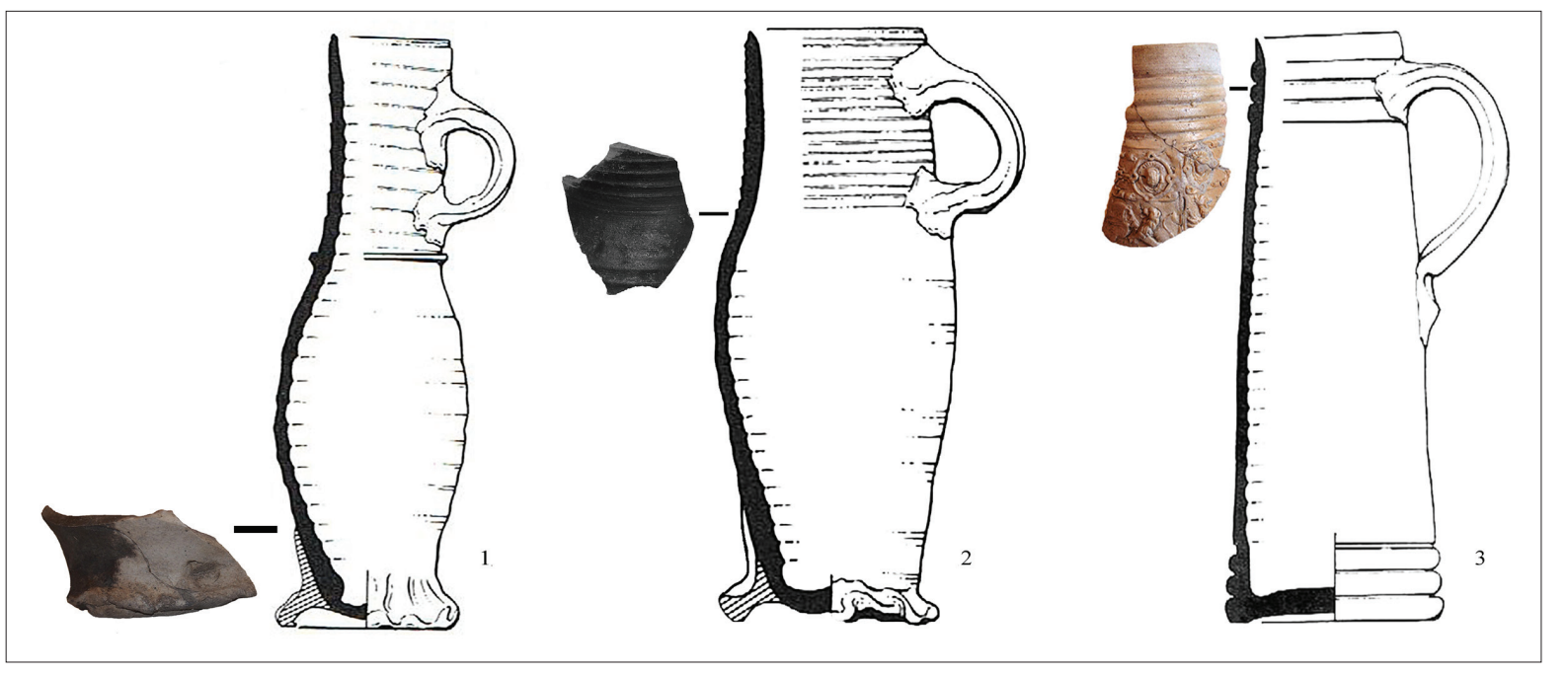

Fig. 1. Examples of Siegburg vessels: 1 a Jacobakanne wine jug; 2 a Jacobakanne beer jug; 3 a salt-glazed Schnelle tankard with relief ornamentation (drawings by D. Gaimster [1997], photographs by the author of the article).

tion sites in the Rhineland (Gaimster 1997). Schnelle tankards usually had silver or tin cover lids. The modest Late Medieval decorative tradition was left behind, and complex compositions appeared with moulding techniques. Biblical, mythological, allegorical, historical and heraldic motifs were a characteristic element of Renaissance stoneware production. Almost the entire surface of vessels was decorated by using two or three different moulds with distinct motifs (Roehmer 2007).

Apart from the new decorative technique, innovative salt glazing started to be the main glazing technique for stoneware. Salt glazing was a costly and dangerous process. A large amount of salt was thrown into the kiln during the firing, when the heat reached a temperature of around 1100 to $1250 \mathrm{C}^{\circ}$ (Rice 2005). During this process, chloride volatised and escaped as a poisonous gas; and as a result, the surface of the pottery became covered in a thin glaze, sometimes in shades of light orange (Rice 2005).

Five fragments of Siegburg salt-glazed and unglazed Schnelle tankards were uncovered in archaeological excavations in Vilnius. Apart from the form and relief ornamentation, these tankards had distinct cordons around the neck and the base, which allow us to identify even small fragments of stoneware. The best example of decorative relief ornamentation on Schnelle tankards was found on Šv Mykolo Street (Sarcevičius 1999, Fig. 1.3). This fragment was salt-glazed, with a light orange colour and two different panels of prints. One depicts a lion with a shield, and the other the head of an Imperial eagle. Unfortunately, the fragment is too small to identify clearly all the relief ornamentation. These motifs were popular during the 16th century, and appeared on many Siegburg stoneware vessels, and most of the arms can be attributed to a specific location. Also, these ornaments usually had supporting inscriptions and dates.

Another interesting example of Renaissance Siegburg production was found at Pilies Street 22 (Kavaliauskas 2000). This drinking jug was decorated with a vertical carved diaper (this ornament is also known as Kerbschnitt). This type of ornamentation appeared during the decline of Siegburg's stoneware production period, around the late 16th century, when potters started to move out and settle in the Westerwald region (Gaimster 1997). These drinking jugs had a pedestal foot, and often the waist of the vessel was decorated with applied moulded ornamentation, such as lion masks, birds or human faces (Gaimster 1997).

\section{Waldenburg stoneware}

Stoneware production also developed in Saxony and Thuringia during the Late Middle Ages; however, production mainly just met local demand. Nevertheless, Waldenburg stoneware is widespread around Europe, and is found in Scandinavia, Poland and in the Baltic States (Gaimster 1997). The production of Waldenburg stoneware started during the 15th century, and lasted until recently, but on a much reduced scale. The good location, made suitable by the clay deposits and the high local demand, was a favourable situation for the long-distance trade in Waldenburg vessels from the 15th to the 17th centuries. The heyday of Waldenburg production was in the 15th century, after which trading declined due to the unstable political situation (Gaimster 1997; Scheidemantel 2005). According to Scheidemantel (2005), Waldenburg production reached its peak with the production of Jacobakanne jugs, which were the main competitor for Siegburg
THE MATERIAL OF MEDIEVAL AND NEW AGES: SOCIAL INTERACTIONS BETWEEN COMMUNITIES 


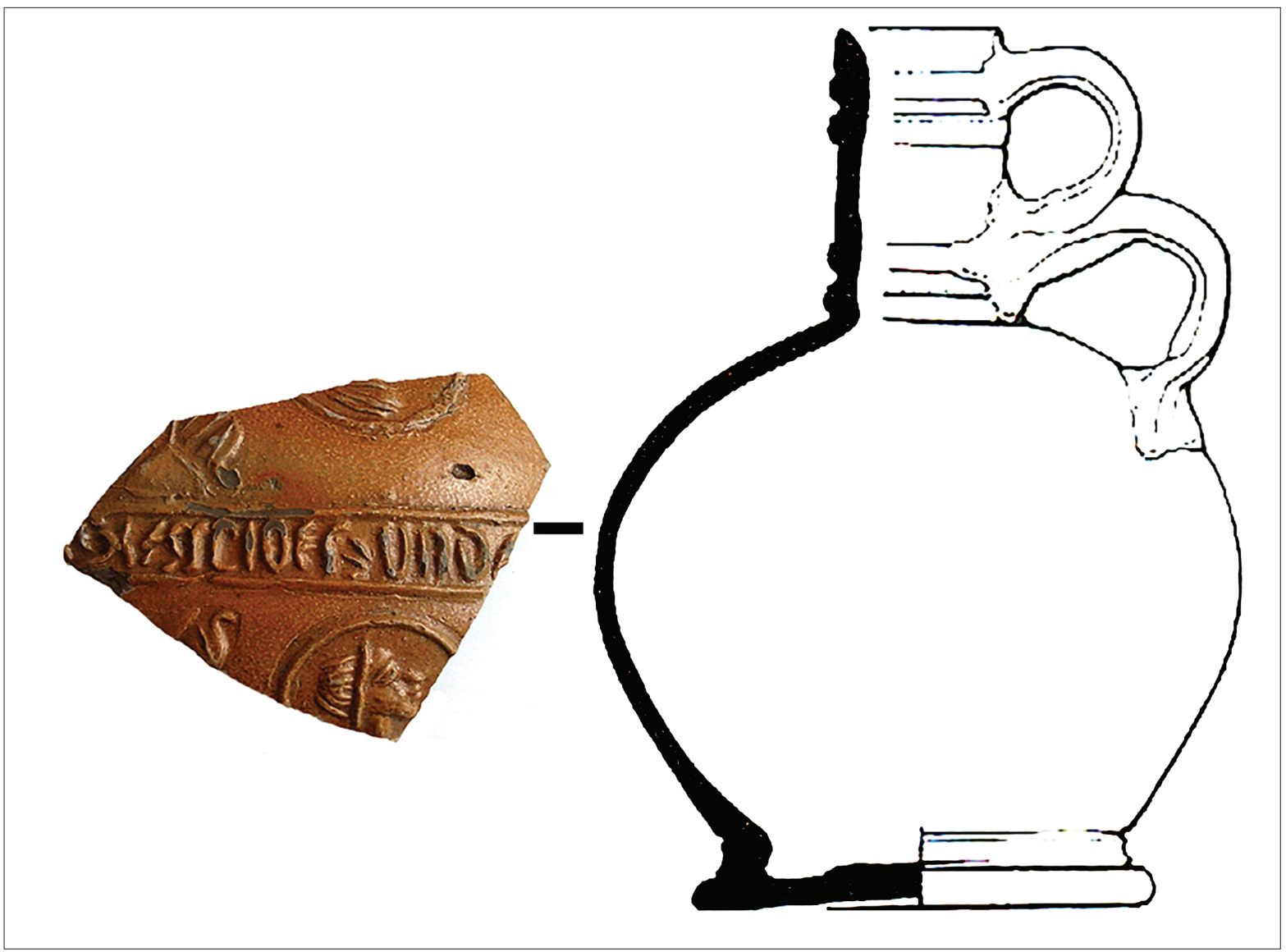

Fig. 2. A fragment of an inscribed jug from the Cologne production centre (drawing by D. Gaimster [1997], photograph by the author of the article).

jugs. It is also believed that the long-distance trade in Waldenburg stoneware during the 15 th century is closely associated with the Hansa trading system in northern Europe, and declined simultaneously with it (Scheidemantel 2005).

Early Waldenburg stoneware is visually similar to Siegburg production; however, its surface is covered with a shiny glaze, and naturally has differing shades of brown, due to the specific features of the clay (Gaimster 1997). In later phases of Waldenburg stoneware production, the surface became a darker brown, and was decorated with stamps and face masks. These jugs are also known in German by the term Gesichtskrug.

Even though stoneware production in Waldenburg started during the 14th century, most artefacts found in Europe date from the 15th century, and are associated with the large-scale import of them. Seven fragments of Waldenburg Jacobakanne jugs were identified and dated to the 15 th century. These jugs differ from Siegburg production in that they had a flat base with sharper thumb impressions, thinner walls, and shallower angular rilling than Siegburg production (Gaimster 1997). Also, concentric wire marks are visible on the underside of the base, which is uncommon for Siegburg stoneware.

Except for one fragment from Vilnius' Old Town, all the other finds are from the excavations in the Lower Castle, and have been dated to the 15 th century. No later Waldenburg imports were found in archaeological excavations. This information corresponds with the wider situation of imported pottery from Waldenburg in Europe. Jacobakanne jugs from Waldenburg were more common than those from Siegburg, and this tendency is also seen in other parts of Lithuania, for example, in the archaeological material from Klaipeda Castle (Ubis 2013).

\section{Cologne stoneware}

Cologne produced stoneware only in the first half of the 16th century, and by the end of the century the potters had moved to Frechen. Despite having the shortest life-span of all the Rhineland producton sites, Cologne potters were the most successful in adopting mould relief techniques, and their products were valued as being of the highest quality. 
Four different stoneware kiln sites were excavated in the centre of Cologne (Unger 2007). Historical sources mention that the local government opposed stoneware production within the town. The authorities were concerned about the poisonous fumes and the high risk of fire posed by kilns (Gaimster 1997). Various prohibitions and taxes forced potters to move to Frechen, and this resulted in the total decline of stoneware production during the second half of the 16th century.

Cologne stoneware is identified by its grey or pinkishgrey shades, and salt-glazed brown surface. The main vessels were Barmann jugs, tankards and pitchers. According to the forms and the technical aspects, Cologne and Frechen stoneware products are very similar, due to the migration of potters. The standardisation of vessels and the decoration are very clear in both places of production (Unger 2007). In some cases, it is impossible to identify whether a specific vessel was made during the later phase of Cologne production or early Frechen.

Only one fragment directly associated with Cologne production was found in L. Gucevičiaus Street (Dzikas 1988, Fig. 2). The surface of this fragment had a bright brown dull gloss, while the body mass was dark grey. The fragment of jug is decorated with relief medallions with the faces of peasants. Around the waist there is a broad band moulded with the writing ,... EST VND ...'. Some of the letters were impossible to identify, and it might be associated with mistakes made during the production of the mould. Cologne stoneware vessels were often decorated with popular maxims. Moulds with human faces were made according to the Antique tradition of depicting nobles and peasants. Besides inscriptions, Cologne potters decorated vessels with oak leaves, acorns, roses and thistles.

\section{Raeren stoneware}

The Raeren stoneware production site is in present-day Belgium, near the border with Germany. Stoneware production started in Raeren and the nearby towns of Eupen, Aachen and other smaller towns during the Late Medieval Period. The site was surrounded by timber, clay and water resources, which are necessary for producing stoneware. Raeren production is classified according to the forms and decoration of the vessels. Even though Raeren potters started producing stoneware in the early 15th century, small amounts of artefacts are found in Europe. According to Gaimster (1997), early Raeren production was rarely exported, and mainly supported the local market. The decline of production started during the late 16 th century, when potters and craftsmen from Siegburg settled in the Westerwald area.

The situation changed in the late 15 th century, with the growing scale of production and long-distance trading. The first period of Raeren stoneware production is from around 1475 to 1550 . Globular mugs and funnelnecked drinking jugs, tankards and washing vessels were the most common types of stoneware. A fragment of a base of a drinking mug with thumbed feet has been uncovered in Didžioji Street (Patkauskas 1978, Fig. 3.1). This vessel is associated with the earliest phase of Raeren stoneware. The thumbed feet decoration was an imitation of Siegburg stoneware. The surface of the jug was treated with an iron wash, which coloured the vessels uneven shades of brown, in this case bright brown. The body colour of Raeren stoneware in this period was grey, with inclusions of yellow. According to Mennicken (2006), different colours in the ceramic body suggest the uneven distribution of the heat in the kiln, and yellow clay in a sherd indicates insufficient heat in the firing process. Two funnel-necked drinking jugs were also attributed to the first phase. The main technical difference is that these jugs were covered in a pattern of brown spots, which appeared naturally during the firing process due to the high levels of iron in the clay deposits (Mennicken 2006).

During the second production period from around 1550 to 1620 , Raeren potters started to decorate vessels with relief moulds. This innovation was borrowed from Cologne and Siegburg potters to remain competitive in the stoneware market. Tankards, pitchers and simple jugs became the most popular type of drinking vessel. Close political ties with the Spanish Netherlands influenced some specific decoration, with Spanish coats of arms or the face masks of political figures of the time. The main features of the stoneware are the grey body mass, the iron washed and salt-glazed surface, and the relief ornamentation. Only two fragments were uncovered in archaeological excavations, and this can be explained by reduced exports of Raeren stoneware. Nevertheless, these jugs are typical Raeren products. They were covered with a brown iron wash, and then salt-glazed. Also, one pitcher with a bearded face mask on the neck was found (Fig. 3.2). This vessel was covered with small brown dots and salt-glazed. The bearded face of a man is also known as Bartmann, and vessels with it are often called Bartmannkrug. Bartmann, or Wild Man, was a mythical creature, and is often depicted in Renaissance manuscripts, textiles, graphic art and architecture (Gaimster 1997). This bearded face of a man is very common in 16th and 17th-century Frechen and Cologne stoneware, and it is also found in Raeren stoneware waste (Gaimster 1997).

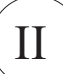

THE MATERIAL OF MEDIEVAL AND NEW AGES: SOCIAL INTERACTIONS BETWEEN COMMUNITIES 

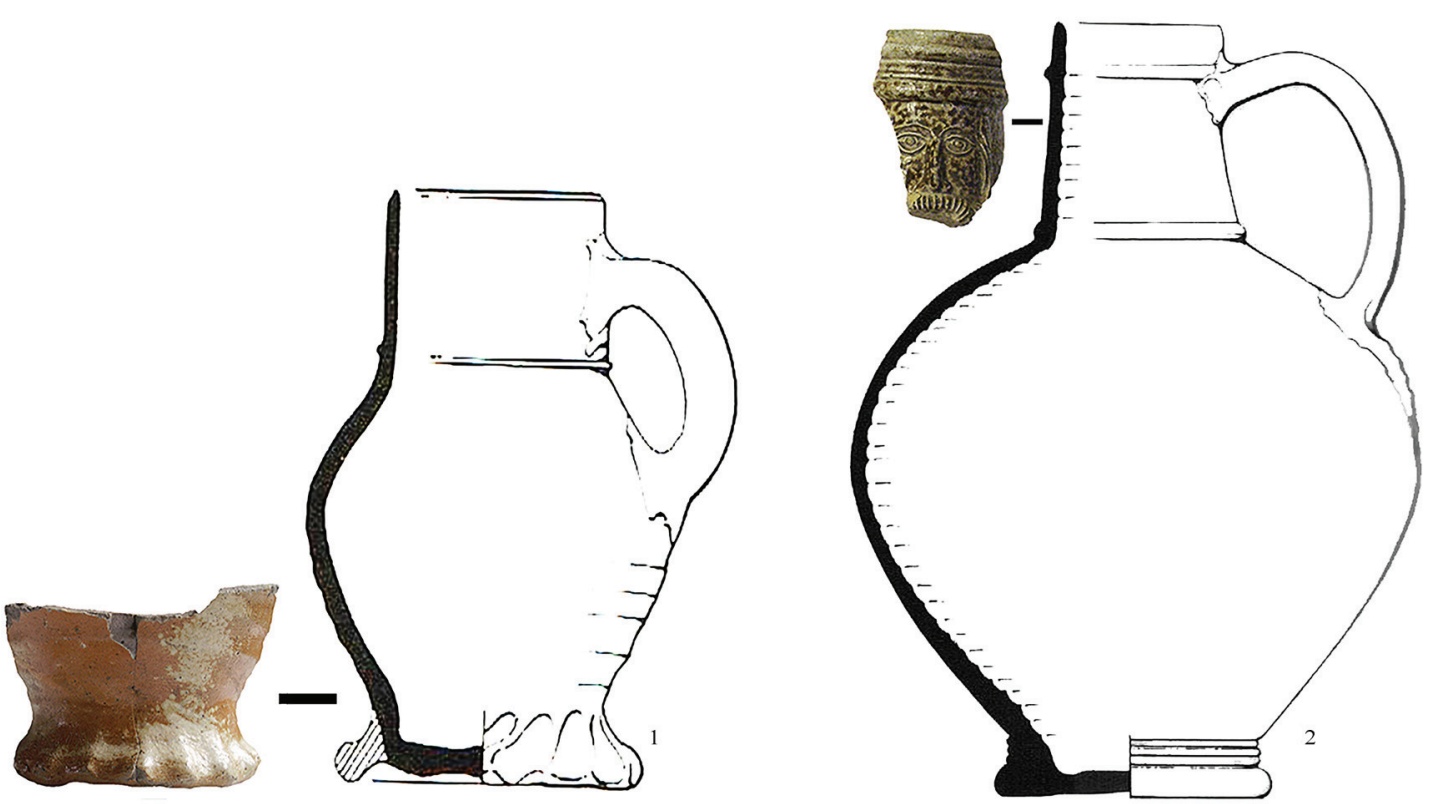

Fig. 3. Raeren stoneware: 1 a drinking mug with thumbed feet; 2 a fragment of a Bartmann jug (drawings by D. Gaimster [1997], photographs by the author of the article).

\section{Frechen stoneware}

The Frechen production site is ten kilometres from Cologne. Frechen stoneware was one of the most widely traded of all Rhenish stoneware, and was found as far away as North America and the coast of Australia (Gaimster 1997). The Frechen site was established when Cologne potters moved to the area and continued their technical and decorative stoneware traditions. However, Frechen managed to become famous for Bartmann jugs, which were the main export and trading item in the 17 th century.

Frechen production is identified by different shades of grey stoneware with a brown iron wash under a speckled salt-glaze. However, during the early stages of production, most of the stoneware was similar or identical to that from Cologne. Early Frechen stoneware jugs dating from the second half of the 16th century are identified by the pinkish colour of the body and the wire marks on the underside of the feet. These marks are good indicators of early Frechen potters, for no such marks are found in Cologne stoneware waste (Unger 2007). Cologne potters took the vessel from a fast wheel that was still, while Frechen craftsmen cut the vessel off while it was still turning. Another hypothesis is that Cologne potters deliberately wiped the base of the vessel (Gaimster 1997). Another Vilnius fragment was identified by the common relief rose applied to a vessel's body with a light speckled salt-glazed surface.
Seventeenth-century stoneware vessels were mainly grey or dark grey, with a darker iron wash under a shiny salt-glaze. Eight fragments of Bartmann jugs were identified in the archaeological material. One important vessel with inscriptions was found at Didžioji Street 8, 10 (Poška 1993, Fig. 4). The fragments of pitcher were decorated with acanthus leaves and medallion face masks, probably of noble people, according to the accessories depicted. Around the waist was a broad band moulded with the words, ARM VND FROMM IST MEIN RICHTVM', meaning, To be poor and pious is my wealth' (Unger 2007; Gaimster 1997). There were many more popular maxims used on stoneware during the 16th and 17th centuries. Writing on vessels is associated with the higher literacy in German and other West European societies, and could have served as an individual expression of political or religous belief (Gaimster 1997). This pitcher was found in cultural layers dating from the 17th century, when, according to historical records, the house belonged to the Dominicans, and was located close to one of the first pharmacies in Vilnius (Valiušyte 1990 cited Poška 1993). As friars were some of the best-educated individuals in society, it might suggest that the pitcher was bought intentionally, knowing the meaning of the inscription. On the other hand, other less literate individuals probably could not understand the meaning of inscriptions, and such vessels did not play a significant role. 


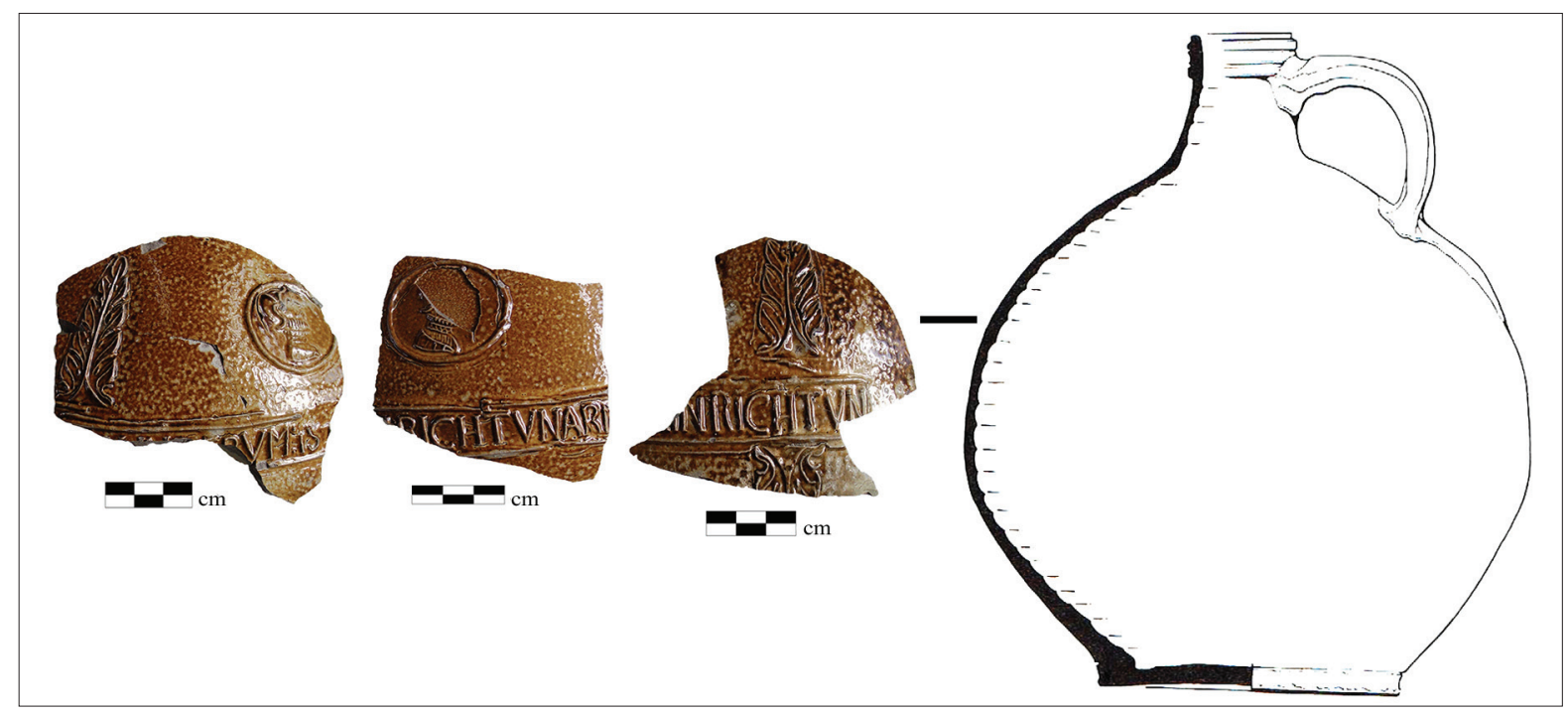

Fig. 4. A Frechen jug with a text in relief: 'ARM VND FROMM IST MEIN RICHTVM' (drawing by D. Gaimster (1997), photographs by the author of the article)

\section{Westerwald stoneware}

Westerwald stoneware production was established in nine different settlements in close proximity to each other. Despite the separate locations, potters used the same clay deposits and decorative techniques. The success and wide distribution of Westerwald stoneware was determined by the largest suitable clay deposits in all of northwest Europe. The migration of potters from Siegburg and Raeren at the end of the 16th century had a significant impact on the scale and quality of production in Westerwald during the 17th century (Gaimster 1997). Westerwald stoneware is found in Europe, North America, Africa, the Far East and Australia. Production declined in the middle of the 18th century, with the introduction of industrial stoneware. Nevertheless, the production of traditional stoneware still goes on to this day.

Westerwald production is easily identified by the grey or light grey stoneware, with vivid blue and manganese colours under a shiny salt-glaze. These two colours were the only pigments capable of withstanding such high firing temperatures until the 20th century, when new techniques appeared (Gaimster 1997). Biblical, mythological, political and everyday situations, and heraldic motifs, were the most common relief ornamentation in Westerwald. During the second half of the 17th century, Westerwald stoneware was influenced by the Baroque style. Thus, the predominant decoration was replaced by rosettes, flowers, berry-prints, fruit, lions ' heads and stars, arranged in rows, stems or geometrical forms (Gaimster 1997). The decoration was either applied by moulds or incised. Also during this period, monochrome stoneware with applied relief and carved diaper ornamentation (Kerbschnitt) was introduced, which is also found in Siegburg production from the second half of the 16th century. Despite the changing decorative motifs, the technical aspects of Westerwald stoneware remained the same during the 17 th and 18 th centuries.

Westerwald production is the most common of all stoneware found in the archaeological context in Vilnius and dating from the 17th and early 18 th centuries. Fifty different sherds were identified and classified according to their decorative motifs. Most of the fragments are typical late 17 th or 18th-century products, with inscribed floral or geometric ornamentation; however, some interesting 17 th-century fragments, with dates, arms and inscriptions, were found.

A fragment of a jug with a coat of arms and an individual's face was uncovered in 1989 on Dominikonu Street. There are also some discernible letters on the arches: ,HA' and ,VS' on the other side. The coat of arms depicts two swords and a bow (?). Attempts to identify the letters and heraldic motif were unsuccessful.

Another small fragment of a tankard depicts a feast with three standing and drinking figures surrounded by repeated panels within arches. The upper body is applied with one repeated rectangular panel in manganese colour, while the other panels are covered in cobalt blue. Based on the decoration, it has been dated to the end of the 17 th century.

A fragment of a jug with King Louis XIV of France painted in cobalt blue was found in the Bernardine convent at Maironio Street 11 (Stanaitis 1994, Fig. 5). It
THE MATERIAL OF MEDIEVAL AND NEW AGES: SOCIAL INTERACTIONS BETWEEN COMMUNITIES 


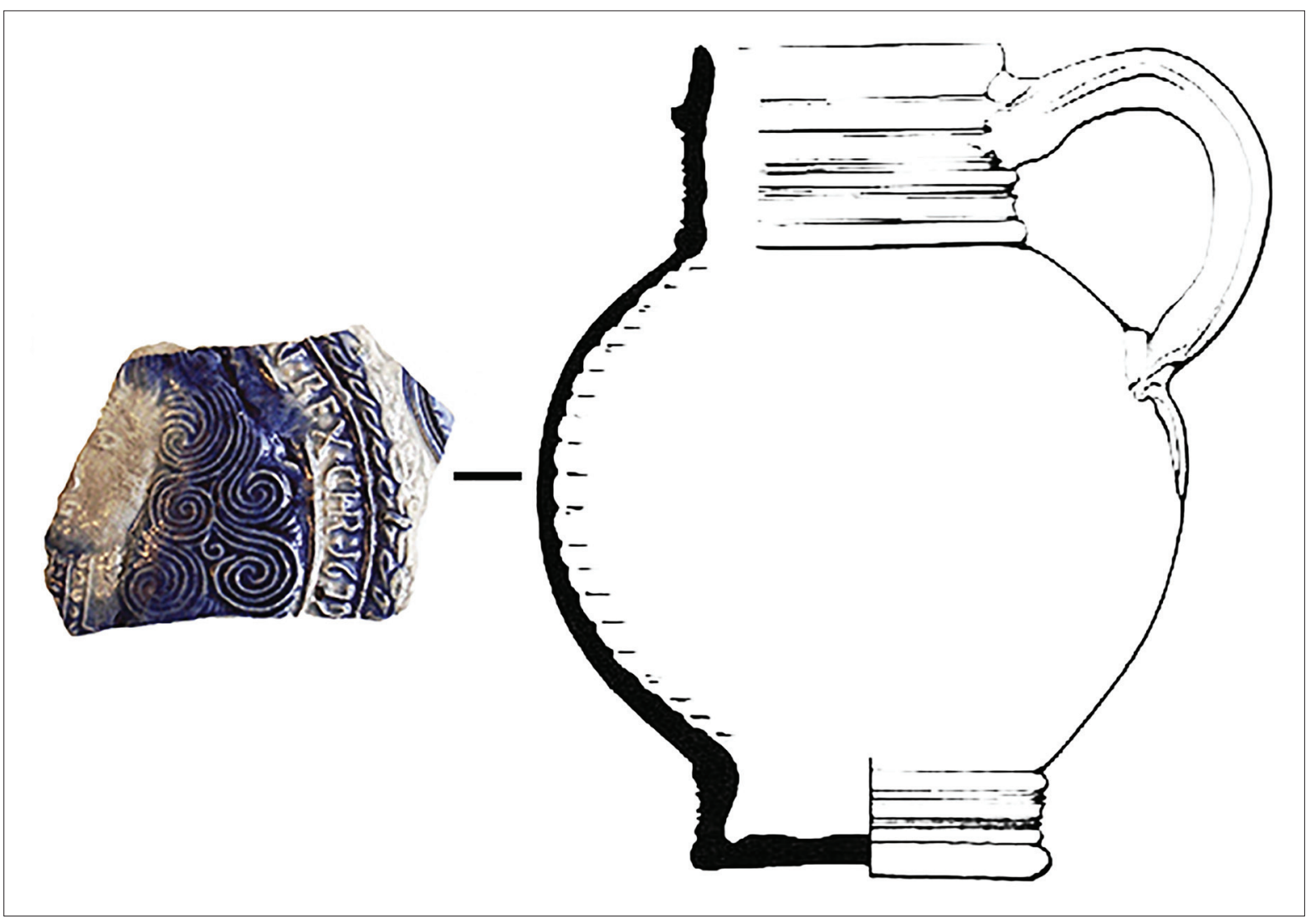

Fig. 5. A jug from the Westerwald region with a bust of Louis XIV (drawing by D. Gaimster [1997], photograph by the author of the article).

has an oval medallion moulded with a bust of Louis XIV, and the inscription ,... REX.CHR: $1679^{\circ}$ on the body of the vessel. The whole inscription would have read ,LVDOVICVS. XIIII. FRANCIA. ET. N. REX. CHR: 1679 '. Vessels with depictions of foreign rulers or local magnates were popular during the 17 th century, and were produced mainly for export to the countries of the rulers depicted. During the 17 th century, individuals of a higher social class liked expressing their political sympathies, and vessels were a suitable item to do this, even in the home environment (Gaimster 1997). However, in the Bernardine convent, the nuns were not allowed to have personal property, or even to leave the convent, so this jug could not be interpreted as a medium for expressing political beliefs. The reason why this jug, with the face of the King of France, was used in the convent is still not known, and probably no direct connection with France can be made in this case. The explanation could be as simple as being a decorative vessel used for dining or religious practices.

\section{Discussion and interpretation}

The interpretation and connection of Late Medieval and Early Modern Period pottery assemblages with historical records from households is made complicated by depositional factors and the development of the landscape carried out over the history of the urban sites. Stratified archaeological contexts, such as latrines, wells and pits, provide information of greater accuracy and reliability than other contexts. However, the analysed stoneware was found in both stratified sites and as objects, and as stray finds. Of course, the limitations of analyses based on only one type of pottery should be taken into account, and do not claim to be definitive; however, some preliminary remarks and hypotheses can be made. This discussion is based on an approach suggested by Blake (1980), whereby it is understood that ceramic vessels provide evidence of demand. Studies are conducted by assessing the types of sites where they were found, ranked on a socio-economic scale. Basic distribution trends and find locations from different periods can be distinguished.

Late Medieval archaeological pottery material consists mainly of locally produced pots; tableware is very rare or absent in most assembleges from this period. However, excavations in the Lower Castle show that wooden cups and ladles were used as drinking vessels and containers for liquid (Kaminskaite 2016). The small quantity of stoneware dated to the 14 th and 15 th centu- 
ries shows that these items were not widely known in the local community. Town dwellers used locally made pots and wooden items for serving food and drinking. Siegburg and Waldenburg vessels were probably used by specific groups of people, most likely newcomers, for whom these vessels were common attributes in their daily life. Generally, a large quantity of Medieval stoneware is found in towns and ports of the Hanseatic League, and is assessed (together with glazed Medieval earthenware and stove tiles) as indicators of urban culture (Gaimster 2014; Mehler 2009). The theory of urban culture in Late Medieval northern Europe suggests that stoneware was brought and introduced to the local community by Germans, firstly by merchants (Gaimster 2014; Mehler 2009). Thus, it is arguable whether the first stoneware in Vilnius was used by Germans, or was brought as containers. Historical sources from the beginning of the 14th century indicate that Grand Duke Gediminas invited German merchants and craftsmen to settle in Vilnius (Rowell 2003). According to Kaplūnaite $(2015,2016)$ and Jonaitis (2016), the first German community settled in the Lower Castle as early as the first quarter of the 14th century. This hypothesis corresponds with the earliest Siegburg finds in this area; however, an analysis of all archaeological assemblages should be made in order to associate these finds with the first German settlers.

Post-Medieval assemblages show a higher quantity of stoneware with a wider distribution in Vilnius' Old Town and the castle area. Vessels with applied mould relief were introduced as early as the beginning of the 16 th century, and are contemporary with trends in Western Europe. The quantity of 16th-century Siegburg, Raeren and Cologne artefacts suggests that stoneware was still a very rare item in the households of town dwellers, and was probably used by individuals of an upper social class. Raeren and Siegburg stoneware was found near the main streets (Pilies, Didžioji, Šv Mykolo), and on trading routes, which were mainly settled by nobles (Drèma 2013; Valionienè 2008, 2015). During the 16th century, more imported pottery, such as Italian and Dutch maiolica, appeared in archaeological assembleges (Urbonaitė-Ubè 2015). The larger amount of imported goods can be linked with closer connections with Western Europe, and with social and cultural changes in local communities.

Seventeenth-century Bartmann jugs from Frechen, and colourful Westerwald vessels, were found in many archaeological assembleges. Stoneware vessels with popular maxims and images of rulers are primarily associated with these production sites. The appearance of religious inscriptions and ornamentation on stoneware vessels is associated with the 16th and 17th-century religous conflicts between Catholics and Protestants
(Gaimster 1997). The pitcher with a religious inscription found in the Dominican friary suggests a direct link between this popular maxim and their beliefs. It can be assumed that a higher level of literacy in society could also have caused a higher demand for inscribed stoneware (Gaimster 1997). The clergy were one of the most educated groups in society, so this pitcher might well have been selected intentionally for its religious message.

The depiction of political figures and coats of arms cannot be directly assessed in the same way as religious inscriptions. The jug with the figure of Louis XIV found in the Bernardine convent is unlikely to have been used as an expression of a political belief, and therefore should be interpreted as a random act. According to Gaimster (1997), it is more usual to find vessels in the North Sea and Baltic regions with Scandinavian rulers rather than Western ones.

No close connections between rich households and the distribution of 17th-century stoneware have been indicated in this research. Further analyses of pottery and other artefacts could reveal patterns of pottery use during this particular period.

\section{Conclusions}

This article analyses only one type of pottery excavated in Vilnius. Stoneware is still one of the earliest imported kinds of pottery found in Vilnius. Stoneware artefacts were identified and classified according to their surface treatment, colour and decorative motifs. The stoneware found in Vilnius was produced in Rhineland production centres, at Siegburg, Cologne, Raeren, Frechen and Westerwald, as well as in Waldenburg in Saxony. It was used for serving liquids, and is counted as tableware used for dining. The different forms of vessels indicate what kind of drink was served or stored.

During the Late Medieval Period, Jacobakanne jugs for wine and beer were the main type of stoneware vessel uncovered in the Lower Castle area. The few finds from this period suggest that the vessels were not common among the local community, and were most likely used by newcomers who probably settled in the Lower Castle area.

During the Early Modern Period, various forms of vessels started to be produced, such as jugs, tankards, pitchers, jars, and various medical and sanitary vessels. The manufacture of stoneware also changed under the influence of the Renaissance, and after the innovation of applied mould relief. The greatest technical innovation was salt-glazing introduced to stoneware production.

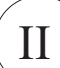

THE MATERIAL OF MEDIEVAL AND NEW AGES: SOCIAL INTERACTIONS BETWEEN COMMUNITIES 
Sixteenth-century Siegburg, Cologne and Raeren stoneware was found along the main trading routes, but only in a few locations in the Old Town, suggesting that it was still a rare and luxurious artefact.

Seventeenth-century Frechen and Westerwald stoneware was found in more varied locations than that from earlier periods. Barmann jugs and vessels, with various kinds of political and domestic decoration and popular maxims, are the most common stoneware artefacts. Since no specific distribution pattern was found, it can be assumed that middle and upper-class town dwellers adopted and used these stoneware vessels in their households.

Identifying imported pottery is a necessary dating tool, as well as material evidence of connections between regions, and even continents. Imported ware could also have had an impact on indigenous pottery manufacturing techniques. Further analysis, both of imported and locally produced pottery assemblages, is necessary for revealing information about the complex social system of Late Medieval and Post-Medieval Vilnius. Further analyses of pottery assemblages could also reveal interesting information about the changing material culture, since it is seen as reflecting social and economic change.

\section{References}

\section{Manuscripts}

DZIKAS, L., 1988. Paskirstomosios kvartalinès šiluminės trasos rekonstrukcija Liejyklos ir J.Janonio gatvių rajone Vilniuje. 1987 m. archeologinè priežiūra ir spejamu Marijos Magdalenos vartų L.Stuokos-Gucevičiaus gatvejje vietos archeologinių tyrimų ataskaita ataskaita (unpublished excavations report). In: Institute of Lithuanian History, Archive, corpus 1, file 1365.

KAMINSKAITĖ, I., 2017. Mediniai dirbiniai Vilniaus Žemutineje pilyje archeologiniais duomenimis. Thesis $(\mathrm{PhD})$. Vilnius University.

KAPLŪNAITĖ, I., 2015. Vilniaus miesto katalikiškoji dalis XIV-XVI amžiaus pradžioje. Thesis (PhD). Klaipèda University.

KAVALIAUSKAS, A., 2000. Žvalgomujų archeologijos tyrimu ir archeologijos tyrimu atliktu $2000 \mathrm{~m}$. Vilniuje, Pilies g. nr. 22, ataskaita (unpublished excavations report). In: Institute of Lithuanian History, Archive, corpus 1, file 3591.

PATKAUSKAS, S., 1978. Archeologinès priežiūros ir fiksacijos darbų Vilniuje, Gorkio 46 ataskaita (unpublished excavations report). In: Institute of Lithuanian History, Archive, corpus 1, file 644 .

POŠKA, T. 1993. Archeologiniai tyrimai Vilniuje, Didžioji g. 8,10. $1993 \mathrm{~m}$. Ataskaita (unpublished excavations report). In: Institute of Lithuanian History, Archive, corpus 1 , file 2162

SARCEVIČIUS, S., 1999. Archeologinių tyrimų, vykdytų Vilniuje - 1998 m. šv. Mykolo gt. nr. 6 ataskaita (unpub- lished excavations report). In: Institute of Lithuanian History, Archive, corpus 1, file 3165.

STANAITIS, A., 1994 m. archeologiniai tyrimai VIlniuje, Maironio g. nr. 11, buv. bernardinių vienuolyno teritorijoje (unpublished excavations report). In: Institute of Lithuanian History, Archive, corpus 1, file 2238.

TAUTAVIČIUS, A., 1962. Ataskaita už archeologinius kasinèjimus Vilniaus Žemutinès pilies teritorijoje nuo 1961 m. gegužès 9 d. iki rugpiūčio 30 d (unpublished excavations report). In: Institute of Lithuanian History, Archive, corpus 1 , file 171 .

UBIS, E., 2012. Klaipédos pilies XIII-XIV a. keraminiai in$d a i$. Thesis (Master). Klaipeda University.

VALIONIENE, O., 2015. Vilniaus erdviné struktūra viduramžiais. Thesis (Phd). Klaipèda University.

\section{Published sources}

Chartularium Lithuaniae res gestas magni ducis Gedeminne illustrans. Gedimino laiškai. 2003. S.C. ROWELL (ed.), Vilnius: Vaga.

\section{Literature}

BLAKE, H., 1980. Technology, Supply or Demand. Medieval Ceramics, 4, 3-12.

DRĖMA, V., 2013. Dingęs Vilnius. 2nd ed. Vilnius: Versus Aureus.

GAIMSTER, D., 1987. The supply of Rhenish stoneware to London 1350-1600. London Archaeologist, 5 (13), 339347.

GAIMSTER, D., 1997. German Stoneware 1200-1900. Archaeology and cultural history. London: British Museum Press.

GAIMSTER, D.R.M., 2006. The Historical Archaeology of Pottery Supply and Demand in the Lower Rhineland, AD 1400-1800. Studies in Contemporary and Historical Arcaheology. BAR International Series 1518, Oxford: Archeopress.

GAIMSTER, D., 2014. The Hansaetic Cultural Signature: Exploring Globalization on the Micro-Scale in Late Medieval Northern Europe. European Journal of Archaeology, 17 (1), 60-81.

HOOF, D.R., 1997. Provenancing Rhenish Stoneware using Neutron Activation Analysis. In: D. GAIMSTER German Stoneware 1200-1900. Archaeology and cultural history. London: British Museum Press, 344-353.

JONAITIS, R., KAPLŪNAITĖ, I., 2016. Panašūs ar skirtingi? Dvi krikščioniškos bendruomenès pagoniškajama Vilniuje. Acta Historica Universitatis Klaipedensis, XXXIII, 75-98.

MENNICKEN, R., 2006. Raeren Steinzeug: technishe und kunsterlische Entwicklungen. In: R. MENNICKEN (ed.) Beiträge zum 38. Keramik zwischen Rhein und Maas. Keramische Begegnungen mit Belgien und den Niederlanden. Internationalen Hafnereisymposium des Arbeitskreises für Keramikforschung im Töpfereimuseum Raeren, 1924 September 2005 Raeren. Raeren: Töpfereimuseum Raeren, 30-46.

MEHLER, N., 2009. The Perception and Interpretation of Hanseatic Material Culture in the North Atlantic: Problems and Suggestions. Journal of the North Atlantic, 1, 89-108. RICE, P., 2005. Pottery Analysis. 2nd ed. Chicago: The University of Chicago Press. 
ROEHMER, M., 2007. Siegburger Steinzeug. Die Sammlung Schulte in Meschede. Mainz am Rhein: Philipp von Zabern.

SCHEIDEMANTEL, D., 2006. Waldenburg Steinzeug aus Spätmittelalter und Früher Neuzeit. In: R. MENNICKEN (ed.) Beiträge zum 38. Keramik zwischen Rhein und Maas. Keramische Begegnungen mit Belgien und den Niederlanden. Internationalen Hafnereisymposium des Arbeitskreises für Keramikforschung im Töpfereimuseum Raeren, 19-24 September 2005 Raeren. Raeren: Töpfereimuseum Raeren, 164-175.

UNGER, I., 2007. Kölner und Frechener Steinzeug der Renaissance. Die Bestände des Kölnishen Stadtmuseums. Köln: Druckhaus LOCHER.

URBONAITĖ-UBE், M., 2015. The Eariest Maiolica Ceramic Dishes in the Old Town in Vilnius. Archaeologia Baltica, 21-22, Klaipèda: Klaipèda University Press.

VALIONIENĖ, O., 2009. Viduramžių Vilnius: planinès struktūros raida XIV-XV a. Lietuvos pilys, 4, 54-61.

Received: 2 February 2018; Revised: 21 September 2018; Accepted: 30 October 2018.

Miglè Urbonaitè-Ubè

Institute of Baltic Region History and Archaeology

Klaipeda University

84 Herkaus Manto St

LT-92294 Klaipèda

Lithuania

E-mail: migle.ube@gmail.com

XIV-XVII AMŽIŲ

AKMENS MASÉS RADINIAI

VILNIAUS ARCHEOLOGINÉJE MEDŽIAGOJE

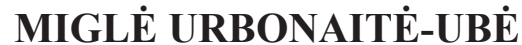

\section{Santrauka}

Lietuvoje kol kas menkai pažistama XIV-XVII amžiu vietinè ir importuota keramika. Apskritai keraminiai indai yra vieni iš chronologijai jautriausių objektų, tad jų tipologija ir identifikacija leistų tiksliau datuoti objektus ir tam tikru laikotarpiu visuomeneje vykusius procesus. Keraminių indų, ypač importuotų, analizė padeda tiriant prekybos ryšius, kultūrines sąveikas ir besikeičiančius žmoniu ịpročius. Viena iš informatyviausių importuotos keramikos rūšių yra akmens masès indai. Akmens masès keramika apibrěžiama ir identifikuojama pagal visiškai susilydžiusią molio masę, kuri pasižymi kietumu ir skysčių nepralaidumu. Šie indai dèl savo specifinių savybių (nepralaidumas, atsparumas kvapams) dažniausiai buvo naudojami skysčiams laikyti ir serviruoti. Vèlyvaisiais viduramžiais ir naujaisiais laikais šios keramikos aptinkama visuose apgyventuose pasaulio žemynuose. Šių indų paplitimas ir kiekis rodo, jog tai buvo viena paklausiausių to meto prekių.

Akmens masės indų analizè atskleidè, kad ị Vilnių ji buvo importuojama iš Reino regiono ir Saksonijos gamybos centru (Zygburgo, Kelno, Raereno, Frecheno, Vestervaldo ir Valdenburgo). Akmens masè identifikuojama pagal susilydžiusią molio masę ir jos spalvas, paviršiaus apdirbimą ir dekorą. Gamybos centrai turèjo ganètinai aiškias dekoravimo ir technologiju taikymo tradicijas. Viduramžių Zygburgo indai buvo neglazūruoti arba padengti matine pelenų glazūra, kuri atpažistama iš ryškios oranžinès spalvos ir netolygiai padengto indų paviršiaus. To paties laikotarpio Valdenburgo indai yra gana panašūs i Zygburgo produkciją, tačiau jų paviršius yra blizgus, o indų sienelès plonesnès, su siauresnemis žiedimo linijomis. Būdingiausias XIV-XV a. akmens masės indų bruožas yra pirštais suformuota indo kojelè. Vilniuje šių centrų indai yra Jacobakanne tipo ąsočiai, skirti vynui ir alui degustuoti, bei druskos glazūra dengti ir reljefiniais ornamentais puošti bokalai.

Kelno akmens masès dirbiniai išsiskiria ruda druskos glazūra, pilka akmens mase ir puošniais reljefiniais ornamentais bei užrašais. Vienas pūstašonio ąsočio fragmentas su užrašu ,EST VND“ ir antikinio stiliaus portretais aptiktas L. Gucevičiaus gatveje. Kelno gamybos centras sunyko XVI a. antrojoje pusèje, kai miesto valdžia uždraudè vykdyti akmens masès gamybą, o puodžiai persikèlè ị Frecheno miestą ir ten tęsè tradiciją.

Raereno akmens masès indai pagal formas ir paviršiaus apdirbimą skirstomi ị du chronologinius etapus. Pirmuoju laikotarpiu (XV a. pabaigoje - XVI a. viduryje) Raerene gaminti geležies angobu dengti indai su pirštu ịspaudais dekoruotomis kojelèmis. Vèliau (XVI a. viduryje - XVII a. pradžioje), perèmus reljefiniu ornamentų madą iš kitų centrų, indai buvo puošiami reljefiniais ornamentais ir dengiami druskos glazūra. Raereno indai pasižymi pilka molio mase ir ryškiu rudu geležies angobu arba taškuotu paviršiumi, kuris susiformuoja degimo krosnyje metu. Pradedami gaminti ir Bartmann tipo ąsočiai bei buteliai su barzdoto vyro atvaizdu, kurie itin išpopuliareja kartu su Frecheno gamybos vietos suklestejimu.

XVII a. Frechenas kartu su Vestervaldo centru tampa akmens masės gamybos lyderiais. Ankstyvoji Frecheno miesto produkcija yra itin panaši į Kelno dèl iš šio miesto atsikèlusių puodžių. Frecheno akmens masė yra pilkai rausva ar pilka, po druskos glazūra paviršius netolygiai padengtas taškeliais. Šis centras daugiausia garsèja Bartmann tipo ąsočiais su vyro atvaizdu ir įvairiais užrašais. Vilniuje buvusiame dominikony valdomame pastate aptiktas pūstašonis ąsotis su užrašu

\section{II}

THE MATERIAL OF MEDIEVAL AND NEW AGES: SOCIAL INTERACTIONS BETWEEN COMMUNITIES 
,ARM VND FROMM IST MEIN RICHTVM“ (,Mano

turtas yra vargas ir dievobaimingumas“). Šiuo laikotarpiu religiniai ir politiniai užrašai ar atvaizdai ant keraminių indų buvo gana populiarūs. Jų atsiradimas siejamas su didesniu visuomenès raštingumu ir įtempta politine situacija bei visuomenès narių noru demonstruoti savo pažiūras.

Vestervaldo akmens masès indai gana lengvai identifikuojami pagal ryškias mèlynas ir violetines spalvas po druskos glazūra, kurios buvo tepamos ant pilkos ar šviesiai pilkos akmens masès. Vestervaldo indai buvo puošiami biblinèmis, mitologinèmis scenomis, taip pat ịvairių Europos šalių herbais ir valdovų atvaizdais. Bernardinių vienuolyne aptiktas mèlynai dengto ąsočio fragmentas su užrašu ,LVDOVICVS. XIIII. FRANCIA. ET. N. REX. CHR: 1679“ ir Liudviko XIV atvaizdu. Tokie gaminiai dažniausiai gaminti pagal užsakymą ir skirti tų šalių gyventojams, tačiau pastebèta, kad neretai tokių indų pasiskirstymas yra atsitiktinis ir negali būti tiesiogiai siejamas su politiniais kontaktais.

Akmens masès radinių skaičius Vilniuje nèra didelis, tačiau jų pažinimas ir identifikavimas padeda archeologinių ir vėlesnių tyrimų metu ieškant atsakymų i praeities klausimus ir tikslinant chronologiją. Šiame straipsnyje analizuojama tik viena iš importuotų keraminių indų rūšių, tačiau jos pažinimas ir susiejimas su istoriniu kontekstu pateikè iki tol neturètų duomenų apie miestiečių gyvenimą XIV-XVII amžiais. 